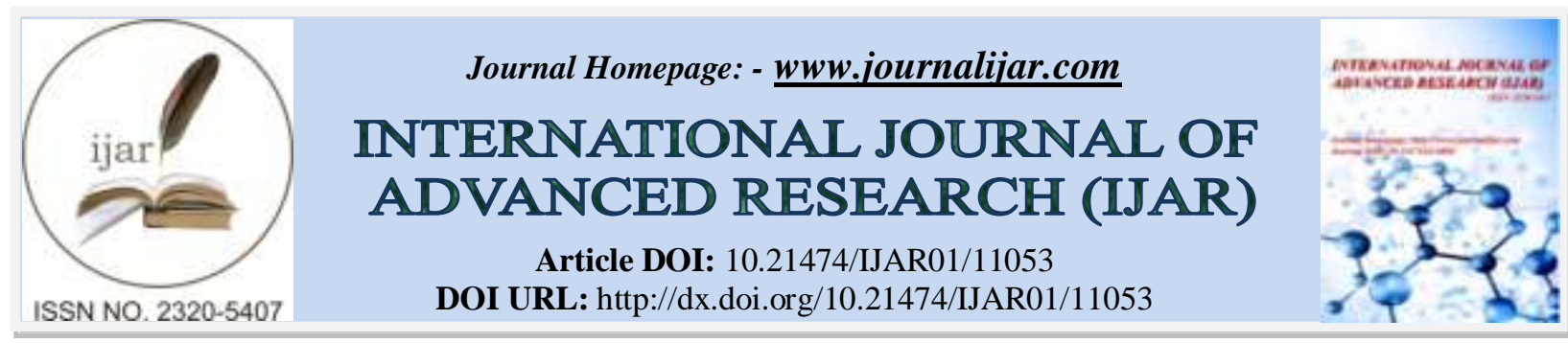

RESEARCH ARTICLE

\title{
A MODEL OF CARBON EMISSION REDUCTION BASED ON THE EFFICACY OF NATIONAL PUBLIC ROAD LIGHTING IN NORTH SUMATERA PROVINCE
}

\author{
Janter Napitupulu ${ }^{1}$, Nasruddin M.N ${ }^{2}$, Immanuel Munthe ${ }^{3}$ and Setia Megawati ${ }^{4}$ \\ 1. Asscociate Professor at Faculty of Engineering, Darma Agung University, Indonesia. \\ 2. Professor at Faculty of Mathematics and Natural Sciences, Sumatera Utara University, Indonesia. \\ 3. Asscociate Professor at Immanuel Industrial Engineering Academy, Indonesia. \\ 4. Lecturer at Sari Mutiara Indonesia University, Indonesia.
}

\section{Manuscript Info}

Manuscript History

Received: 25 March 2020

Final Accepted: 30 April 2020

Published: May 2020

Key words:-

Electric Power, Energy Conservation,

Carbon Emisson, Light Lamp Efficacy

\begin{abstract}
Electrical energy is a fundamental requirement necessary for the survival of human activities. Electrical energy is exploited as much as possible in human life due to its availability which is continuously reachable easily and cleanly. In terms of supply, in its operation, the generation of electrical energy with fossil fuels causes environmental pollution whose value can be converted by multiplying by $1.14 \mathrm{KgCO} 2$ / KWh emission factor. From the demand side, street lighting has a light efficacy that can be used for energy conservation. Light lamp efficacy is the ratio of luminal output to electric power consumption expressed by lumen / watt unit. The efficacy of the lamplight affects the light intensity in the candela unit and the intensity of light affects the illumination in lux units. By using Model Type: Utilization of SUTR power through converter to PJU-LED obtained energy conservation of 40.149 GWh and Utilization of SUTR power through converter to PJULED and DIM obtained energy conservation of 48,897 GWh of national road along the $2632.22 \mathrm{~km}$ in North Sumatera Province, and resulted in a decrease in carbon emissions of 45,769 $\mathrm{kTon}^{\mathrm{CO}_{2}}$ and 55,742 kTon $\mathrm{CO}_{2}$ respectively, resulting in carbon trading values of US $\$ 83,752.27$ and US $\$ 102,013.35$.
\end{abstract}

Copy Right, IJAR, 2020,. All rights reserved.

\section{Introduction:-}

At present, the condition of shortage of electrical energy can occur due to limited supply of electrical energy is smaller than the larger energy needs. The rate of growth of electricity demand will tend to be greater if not addressed will cause the level of availability of electrical energy to be disrupted.

To overcome the limitations of electrical energy, energy conservation efforts are needed[1]. Conservation of electrical energy can be achieved through 2 approaches that are 1.By increasing the efficiency of electrical energy usage and 2. Reducing losses. Conservation efforts can be achieved through two aspects: 1. Aspect of technology and 2. Aspect of human behavior change.

In North Sumatra Province, one method to overcome the limitations of electrical energy is energy conservation based on environment[2]. In the case of electric energy crisis, Bangladesh as one of the developing countries can 
save electricity consumption 3\% -20\% through changes in human behavior[3]. The management of energy efficiency in the consumer side and service sectors is always based on the application of demand side management[4].

The energy absorbed by the cloud and the earth's surface is reflected back in the form of infrared radiation, but some of the infrared radiation emitted by the earth is held up by clouds and gases of carbon dioxide and other greenhouse gases, to be returned back to the earth's surface. In China, Green House Gases emission can be reduced from $\mathrm{N}$ fertilizer[5]. Under normal circumstances, the greenhouse effect is required. With the greenhouse effect the temperature difference between day and night on earth is not too much different.

In the control of regulated air pollution which refers to the maintenance of the environment should be the basis in the development of society[6].

With the electric energy crisis, the development pattern of electric energy generation and the utilization of electrical energy become related to the issue of global warming, so to overcome the thickening of carbon dioxide emission, the utilization of environmentally friendly technology becomes the choice[7].

One of the efforts to obtain potential energy conservation done is on general street lighting due to its use occurs only at night and at the same time the peak load[8]. Particularly for national street lighting a large energy requirement is managed for the convenience of driving at night[9].

To determine the level of carbon emissions caused by the generation and utilization of electrical energy, using data generating electricity in Indonesia, then the $\mathrm{CO} 2$ emission factor is $1.14 \mathrm{Kg} / \mathrm{KWh}$ stated by United Nation Development Project (UNDP).

Referring to the results of the National Strategy Study (NSS) indicating that the CDM potential of the energy sector is about $2.1 \%$ of Indonesia's total 1200 million tons of $\mathrm{CO} 2$ emissions per year. Thus the CDM potential of the energy sector is 25.2 million tons of $\mathrm{CO} 2$ per year at a price of US $\$ 1.83$ per ton.

\section{Theoretical background:}

\section{The Power Absorbed By The Lamp And Power Factor Correction:}

Electrical power is calculated as follows:

$$
\mathrm{P}=\text { V.I. } \operatorname{Cos} \varphi=\mathrm{S} . \operatorname{Cos} \varphi
$$

where: $\mathrm{P}$ is electric power

$\mathrm{V}$ is the utility voltage

I is the electric current

$\operatorname{Cos} \varphi$ is the power factor.

Energy is the power used in a single unit of time.

$$
\mathrm{W}=\mathrm{P} \times \mathrm{t}
$$

where:

$\mathrm{W}$ is energy

$\mathrm{t}$ is time

The energy absorbed by the lamp is

$$
\begin{aligned}
& \mathrm{W}=\mathrm{S} \times \mathrm{t} \\
& \mathrm{W}=(\mathrm{P} / \mathrm{pf}) \times \mathrm{t} \\
& \mathrm{W}=\mathrm{KWh} / \mathrm{pf}
\end{aligned}
$$

Power factor correction(Qc )can be obtained as follows:

$$
\mathrm{Qc}=\mathrm{P}(\tan \varphi 1-\tan \varphi 2)
$$

$$
=\mathrm{V}^{2} / \mathrm{Xc}
$$

The value of adding capacitor(C) for power factor increase is

$$
\mathrm{C}=\mathrm{Qc} / 2 \pi \mathrm{fV}^{2}
$$

With the increase in power factor improvement which means the increase of Cos $\varphi$, will be able to reduce energy generation. This condition can reduce the use of fuel which can ultimately reduce $\mathrm{CO} 2$ emissions generated by the plant. 


\section{Energy Conservation:}

To get energy conservation, applied Model Type: Utilization of SUTR power through converter to PJU-LED and DIM.

\section{Light Efficacy:}

The efficacy of light is the ratio of the lumen output to the power consumption expressed in lumen / watt units.

$$
\mathrm{K}=\varnothing / \mathrm{P}
$$

Where,

$\mathrm{K}$ is the light efficacy $(\mathrm{Lm} / \mathrm{W})$

$\varnothing$ is Flux light $(\mathrm{Lm})$

$\mathrm{P}$ is electric power (Watt)

In street lighting, the height of the lamppost affects the spreading of light. The higher the pole is used, the resulting light widened with a smaller level of illumination.

To determine the angle of the line that connects the endpoint of the lamp and the point in the middle of the road with the horizontal line is as follows in Fig.1

$\mathrm{r}=\sqrt{\mathrm{h}^{2}+\mathrm{c}^{2}}$

$\operatorname{Cos} \psi=\mathrm{h} / \mathrm{r}$

Where,

$r$ is the side of beveled line, the distance from the end of the lamp to the point in the middle of the road,

$\mathrm{c}$ is the horizontal line, the distance from the projection point of the lamp end to the point in the middle of the road, $\mathrm{h}$ is the pole height,

$\psi$ is the angle between $\mathrm{r}$ and $\mathrm{h}$.

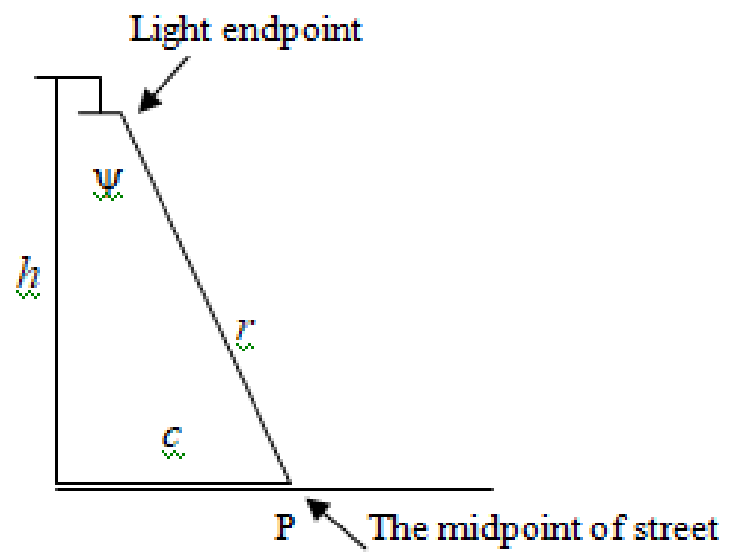

Fig.1:- Effect of lamppost height on illumination.

To calculate the intensity of light (I) in units of candela (cd):

$$
\begin{aligned}
& \mathrm{I}=\varnothing / \omega \\
& \omega=4 \pi \\
& \mathrm{K}=\varnothing / \mathrm{P} \text { or } \emptyset=\mathrm{KxP}
\end{aligned}
$$

Then, $\mathrm{I}=\mathrm{KxP} / 4 \pi$

Illumination $\mathrm{E}_{\mathrm{P}}$ in units of Lux at the point $\mathrm{P}$ in the middle of the street is

$$
\mathrm{E}_{\mathrm{P}}=\mathrm{I} \times \operatorname{Cos} \psi / \mathrm{r}^{2}
$$

\section{Research Method:- \\ Model type:}

Utilization of SUTR power through converter to PJU-LED and DIM:

The P PJUn-SUTR approach model is an approach model with low voltage network (SUTR) as an energy source and High Pressure Mercury Lamp (MBF) is changed to LED Lights as PJU National Public Road Lighting, PJU SUTR-LED. $_{\text {. }}$ Among SUTR and PJU SUTR-LED are used converters that convert alternating current into DC current. Then, used the 


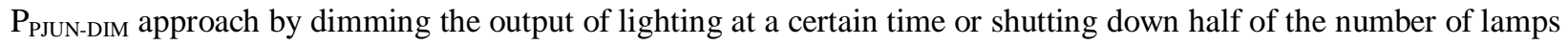
that apply.

Energy conservation can be obtained in 2 stages. In stage 1, energy conservation is obtained from 18:00 to 24:00 WIB, as follows:

$\mathrm{P}_{\text {PJUn-SUTR }}[1]=\left[\mathrm{P}_{\text {SUTR-MBF }}-\left(\mathrm{P}_{\text {SUTR-LED }}+\Delta \mathrm{P}_{\text {Konv }}\right)\right]$

$\mathrm{P}_{\text {Konsv-SUTR }}[1]=\left(\mathrm{P}_{\text {PJUN-SUTR }}[1]\right) \times \mathrm{n}$

$\mathrm{E}_{\text {Konsv-SUTR }}[1]=\mathrm{P}_{\text {Konsv-SUTR }}[1] \times$ Oh

$\mathrm{J}_{\text {Konsv-SUTR }}[1]=\mathrm{E}_{\text {Konsv-SUTR }}[1] \times \mathrm{J}_{\mathrm{E}}$

Where :

$\mathrm{J}_{\text {Konsv-SUTR }}[1]$ : Energy conservation is converted to $\mathrm{CO}_{2}$ emissions $(\mathrm{Kg})$ stage 1

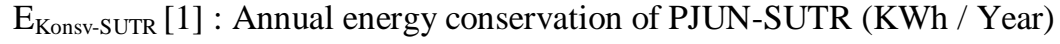

$\mathrm{P}_{\text {Konsv-SUTR }}[1]$ : Power Conservation PJUN-SUTR (KW)

$P_{\text {PIUN-SUTR }}[1] \quad$ : Power of PJUN-SUTR lamp.

$P_{\text {SUTR-MBF }}[1] \quad$ : Power of PJUN-MBF lamp

$P_{\text {SUTR-LED }}[1] \quad$ : Power of SUTR-LED light

$\mathrm{n}:$ Number of lights

Oh : Working hours

$\mathrm{J}_{\mathrm{E}}: \mathrm{CO}_{2}$ Emission Factor $(\mathrm{Kg} / \mathrm{KWh})$

In stage 2, energy conservation is obtained from 24:00 to 06:00 WIB, as follows :

$\mathrm{P}_{\text {PJUn-SUTR }}[2]=1 / 2\left[\mathrm{P}_{\text {SUTR-MBF }}-\left(\mathrm{P}_{\text {SUTR-LED }}+\Delta \mathrm{P}_{\text {Konv }}\right)\right]$

$\mathrm{P}_{\text {Konsv-SUTR }}[2]=\left(\mathrm{P}_{\text {PJUN-SUTR }}[2]\right) \times \mathrm{n}$

$\mathrm{E}_{\text {Konsv-SUTR }}[2]=\mathrm{P}_{\text {Konsv-SUTR }}[2] \times$ Oh

$\mathrm{J}_{\text {Konsv-SUTR }}[2]=\mathrm{E}_{\text {Konsv-SUTR }}[2] \times \mathrm{J}_{\mathrm{E}}$

Where :

$\mathrm{J}_{\text {Konsv-SUTR }}[2]$ : Energy conservation is converted to $\mathrm{CO}_{2}$ emissions $(\mathrm{Kg})$ stage 1

$\mathrm{E}_{\text {Konsv-SUTR }}$ [2] : Annual energy conservation of PJUN-SUTR (KWh / Year)

$\mathrm{P}_{\text {Konsv-SUTR }}[2]$ : Power Conservation PJUN-SUTR (KW)

PJUn-SUTR $_{\text {P2] }}$ : Power of PJUN-SUTR lamp.

P $_{\text {SUTR-MBF }}[2] \quad:$ Power of PJUN-MBF lamp

$\mathrm{P}_{\text {SUTR-LED }}[2] \quad$ : Power of SUTR-LED light

Then,

$\mathrm{J}_{\mathrm{T}}=\mathrm{J}_{\text {Konsv-SUTR }}[1]+\mathbf{J}_{\text {Konsv-SUTR }}[2]$

$\mathrm{J}_{\mathrm{T}}$ : Total energy conservation is converted to $\mathrm{CO}_{2}$ Emissions

\section{Result and Discussion:-}

The effect of height variation of light pole on illumination:

As a reference used MBF, 400 watts, 110 Lumen/watt for primary arterial road.

The effect of the height variation of light poles on the illumination produced with certain light efficacy on the primary arterial road at the midpoint of the road is obtained by the following calculation:

1.Lamp type: MBF, 400 Watt, 53 lumens / watt

Road width: $8 \mathrm{~m}$

$\mathrm{h}=10 \mathrm{~m}$

$\mathrm{c}=2.95 \mathrm{~m}$

$\mathrm{r}=\sqrt{10^{2}+2,95^{2}}$

$=10.426 \mathrm{~m}$

$\operatorname{Cos} \psi=10 / 10.426$

$=0.959$

$I=53 \times 400 /(4 \times 3,14)$

$=1687.898 \mathrm{~cd}$

Then, 
$\mathrm{E}_{\mathrm{P}}=1687.898 \mathrm{x} 0,959 / 10.426^{2}$

$=14.891$ Lux

As a reference used MBF, 180 watts, 53 Lumen/watt for primary collector road.

2.Lamp type: MBF, 180 Watt, 53 lumens / watt

Road width: $7 \mathrm{~m}$

$\mathrm{h}=7 \mathrm{~m}$

$\mathrm{c}=2.6 \mathrm{~m}$

$\mathrm{r}=\sqrt{7^{2}+2.6^{2}}$

$=7.467 \mathrm{~m}$

$\operatorname{Cos} \psi=7 / 7.467$

$=0.937$

$\mathrm{I}=53 \times 180 /(4 \times 3,14)$

$=759.554 \mathrm{~cd}$

Then,

$\mathrm{E}_{\mathrm{P}}=759.554 \mathrm{x} 0,937 / 7.467^{2}$

$=12.764 \mathrm{Lux}$

Using lamp type: LED, 120 watt, 130 lumen / watt For primary arterial road, then

Road width: $8 \mathrm{~m}$

$\mathrm{h}=8 \mathrm{~m}$

$\mathrm{c}=3.1 \mathrm{~m}$

$\mathrm{r}=\sqrt{8^{2}+3.1^{2}}$

$=8.57 \mathrm{~m}$

$\operatorname{Cos} \psi=8 / 8.57$

$=0.93$

$\mathrm{I}=120 \times 130 /(4 \times 3.14)$

$=1242.03 \mathrm{~cd}$

Then,

$\mathrm{E}_{\mathrm{P}}=1242.03 \times 0,93 / 8.57^{2}$

$=15.73 \mathrm{Lux}$

For collector road, then

Road width: $7 \mathrm{~m}$

$\mathrm{h}=8 \mathrm{~m}$

$\mathrm{c}=2.6 \mathrm{~m}$

$r=\sqrt{8^{2}+2.6^{2}}$

$=8.41 \mathrm{~m}$

$\operatorname{Cos} \psi=8 / 8.41$

$=0.95$

$\mathrm{I}=120 \times 130 /(4 \times 3.14)$

$=1242.03 \mathrm{~cd}$

Then,

$\mathrm{E}_{\mathrm{P}}=1242.03 \times 0,95 / 8.41^{2}$

$=16.69 \mathrm{Lux}$

Fossil Electrical Energy Requirements for PJU of National Road Segment:

According to criteria of primary artery road with width of road body is $8 \mathrm{~m}$, requirement of lighting quality is 11- 20 Lux, used lamp lamp of MBF, 400 Watt with $11 \mathrm{~m}$ pole height with $40 \mathrm{~m}$ inter pole distance. For primary collector road with road width is $7 \mathrm{~m}$ using MBF lamp, 180 watt with $8 \mathrm{~m}$ pole height with $40 \mathrm{~m}$ interpole distance.

Therefore, electricity consumption is obtained in 1 year on primary artery road along $1142 \mathrm{Km}$ with operating time 4145 hours in 1 year, as follows:

1. Number of PJU Pillar is (Length of Road/40) +1

2. PJU electrical power

$\mathrm{P}_{\text {PJU-SUTR }}=400 \mathrm{Watt} \mathrm{x}$ Number of posts

$=400$ Watt $\mathrm{x} 28,551$ 


\section{$=11.420 \mathrm{MW}$}

3. PJU electrical energy requirement in one year is

$$
\begin{aligned}
\mathrm{W}_{\text {PJU-SUTR }} & =400 \text { Watt x Number of poles x } 4145 \text { hours } \\
& =400 \text { Watt } \times 28.551 \text { pole } \mathrm{x} \quad 4145 \text { hours } \\
& =47.337 \mathrm{GWh}
\end{aligned}
$$

Electric energy consumption is obtained within 1 year on Collector Primer-1 Road along 1490.22 Km with operating time of 4145 hours in 1 year, as follows:

1. Number of PJU Pillar is (Length of Road / 40)+1

2. PJU electrical power

$$
\begin{aligned}
\text { PJu-SUTR } & =180 \text { Watt } \times \text { Number of posts } \\
& =180 \text { Watt } \times 37.256 \\
& =6,706 \mathrm{MW}
\end{aligned}
$$

3. PJU electrical energy requirement in one year is

$$
\begin{aligned}
\mathrm{W}_{\text {PJU-SUTR }} & =180 \text { Watt } \mathrm{x} \text { Number of poles } \mathrm{x} 4145 \text { hours } \\
& =180 \mathrm{Watt} \times 37.256 \text { pole } \mathrm{x} 4145 \text { hours } \\
& =27.796 \mathrm{GWh}
\end{aligned}
$$

The need for electrical energy PJU-SUTR National Road along 2632.22 Km in 2019 is equal to $75.133 \mathrm{GWh}$.

The need for electrical energy on the utilization of SUTR power through converter to PJU-LED:

Electric energy consumption in 1 year on Primary Arterial Road and Primary Collector Road along 2632,22 Km with operation time 4145 hours in 1 year, as follows:

a.The number of PJU pole is (Length of Road/40) +1

b.PJU electrical power

$$
\begin{aligned}
\text { PIJULED } & =120 \text { Watt } \times \text { Number of poles } \\
& =120 \text { Watt } \times 65,807 \\
& =7,896,840 \mathrm{~W} \\
\mathrm{~W}_{\text {PJU-LED }} & =7,896,840 \times 4145 \\
& =32,732 \mathrm{GWh}
\end{aligned}
$$

Load current,

$$
\begin{aligned}
\mathrm{I}= & 7,896,840 /(220 \times 0,85) \\
& =42,229.09 \mathrm{~A}
\end{aligned}
$$

Losses on SUTR,

$$
\begin{aligned}
\Delta \mathrm{W}_{\text {SUTR }} & =5 \% \times 220 \times 42,229.09 \times 4145 \\
& =1.925 \mathrm{GWh}
\end{aligned}
$$

Losses on the converter,

$$
\Delta \mathrm{W}_{\text {conv }}=1 \% \text { x } 32.732=0.327 \mathrm{GWh}
$$

So, the energy requirement for the national road is

$$
\begin{aligned}
\mathrm{W}_{\mathrm{T}} & =32.732+1.925+0.327 \\
& =34.984 \mathrm{GWh}
\end{aligned}
$$

The need for electrical energy on the utilization of SUTR power through converter to PJU-LED and DIM: When at 18:00 to 24:00 pm, the lights illuminate all, then the need for electrical energy is

$$
\begin{aligned}
\mathrm{W}_{\text {PJU-LED }} & =7,896,840 \times 2072.5 \\
& =16.366 \mathrm{GWh} \\
\Delta \mathrm{W}_{\text {SUTR }} & =5 \% \times 220 \times 42,229.09 \times 2072.5 \\
& =0.962 \mathrm{GWh} \\
\Delta \mathrm{W}_{\text {conv }} & =1 \% \times 16.366=0.163 \mathrm{GWh} \\
\mathrm{W}[1]= & 16.366 \mathrm{GWh}+0.962 \mathrm{GWh}+0.163 \mathrm{GWh} \\
= & 17.491 \mathrm{GWh}
\end{aligned}
$$

When half of the LED bulb is turned off at $24.00-06.00 \mathrm{WIB}$, then the need for electrical energy is

$\mathrm{W}[2]=1 / 2 \times 17.491 \mathrm{GWh}$

$$
=8.745 \mathrm{GWh}
$$

$\mathrm{W}_{\mathrm{T}}=\mathrm{W}[1]+\mathrm{W}[2]$ 
$=17.491 \mathrm{GWh}+8.745 \mathrm{GWh}$

$=26.236 \mathrm{GWh}$

With model type: SUTR power utilization through converter to PJU-LED and DIM obtained energy conservation as in table 1 .

Table 1:- Energy Conservation and obtained the reduction of carbon emissions as in table 2.

\begin{tabular}{ccc}
\hline & $\begin{array}{c}\text { Energy } \\
\text { Requirement }\end{array}$ & $\begin{array}{c}\text { Energy } \\
\text { Conservation }\end{array}$ \\
\cline { 2 - 3 } En . Ref & $\begin{array}{l}\text { With Converter } \\
\text { To PJU-LED }\end{array}$ & $\begin{array}{l}\text { With Converter } \\
\text { to PJU-LED and } \\
\text { DIM } \\
(\mathrm{GWh})\end{array}$ \\
\hline 75.133 & $34.984 \mid 40.149$ & $26.236 \mid 48.897$ \\
\hline
\end{tabular}

Table 2:- $\mathrm{CO}_{2}$ emission reduction.

\begin{tabular}{lcc}
\hline $\begin{array}{r}\text { Emission } \\
\text { Factor }\end{array}$ & $\begin{array}{c}\text { Energy } \\
\text { Conservation } \\
(\mathrm{GWh})\end{array}$ & $\begin{array}{c}\mathrm{CO} \text { Emission } \\
\text { reduction }\left(\mathrm{KgCO}_{2} / \mathrm{kWh}\right) \\
\left(\mathrm{kTon} \mathrm{CO}_{2}\right)\end{array}$ \\
\cline { 2 - 3 } & $\begin{array}{c}\text { With Converter } \\
\text { To PJU-LED }\end{array}$ & $\begin{array}{c}\text { With Converter } \\
\text { to PJU-LED and } \\
\text { DIM }\end{array}$ \\
\hline 1.14 & $40.149 \mid 45.769$ & $48.897 \mid 5.742$ \\
\hline
\end{tabular}

According to the energy sector CDM potential by National Strategy Study (NSS) at a price of US $\$ 1.83$ per ton then, in carbon trading is obtained as follows in Table 3

Table 3:- The Value of Carbon Trading.

\begin{tabular}{cc|c}
\hline $\begin{array}{c}\text { Carbon } \\
\text { price } \\
\text { \$/Ton }\end{array}$ & $\begin{array}{c}\text { CO2 Emission } \\
\text { reduction } \\
\left(\text { kTon } \mathrm{CO}_{2}\right)\end{array}$ & $\begin{array}{c}\text { Carbon Trading } \\
\text { Value } \\
\$\end{array}$ \\
\cline { 2 - 3 } & $\begin{array}{c}\text { With Converter } \\
\text { To PJU-LED }\end{array}$ & $\begin{array}{c}\text { With Converter } \\
\text { to PJU-LED and } \\
\text { DIM }\end{array}$ \\
\hline $83,752.27$ & $55.7421 \phi 2,013.35$ & $\mid$ \\
\hline
\end{tabular}

\section{Conclusion:-}

Energy conservation is an energy efficiency use measure by reducing energy consumption or replacing energy sources to get the same benefits. In this paper, energy conservation is obtained by replacing Lighting lamps of the MBF Lights type into LEDs and between Low Voltage Networks as a converted energy source converter. Obtained energy conservation of $45.769 \mathrm{GWh}$ as a stage 1 and by doing Dimmer as stage 2 obtained energy conservation of 55.742 GWh.

By carrying out conservation measures along the $2632.22 \mathrm{~km}$ national road in North Sumatera Province using LEDDimmer Converter, a carbon emission reduction of 55.742 kTon CO2 was obtained with a carbon trading value of US \$ 102,013.35. Converter technology makes it possible to conserve energy by using LED lights. 


\section{Acknowledgement:-}

Thank you for the support given by the Darma Agung University, for the completion of this research.

\section{References:-}

1. Arvind, D., Tejinder, S., Energy Efficient Lighting- A way to Conserve energy, International Journal of energy, Issu 1, Vol.3, 2009.

2. Janter, N., Nasruddin, M.N., Immanuel, M., Setia, M., Conservation Of Electrical Energy On The National Street Lighting Based On Environment, International Journal Of Advanced Research (IJAR), ISSN 23205407, Vol. 7 Issu 11, November 2019.

3. Khan, I., Halder P.K., 2016. Electrical Energy Conservation Through Human Behavior Change : Perspective in Bangladesh, International Journal of Renewable Energy Reseach. Vol.6, No.1, 2016

4. Mohamed, A., Mohamed, T.K., 2009. A Review Of Elektrical management Techniques Supply and Consumer Side (Industries), Journal Of Energy Southern Africa Vol.20, No.3, August 2009.

5. Fredrich, K., Yunju L., Yufang S., Timn, T., Andreas W., 2010, Greenhouse gas emissions from nitrogen fertilizer use in China, Environmental science \& Policy. Vol.13, Issue 8, Dec. 2010, ISSN 1462-9011.

6. Warner, K., 2010. Global environmental change and migration : Governance challenges, Global Environmental Change Human and Policy Dimension, ISSN: 0959-3780, Vol.20, No.3.

7. Janter, N., Herman, M., Usman, B., Nasruddin, M.N., Model Of Sustainable Electrical Power management: In Term Of lamp Efficacy Of The National Street Lighting In North Sumatera Province, International Journal of Advanced Research (IJAR), ISSN: 2320-5407, Vol.6, Issu 3, Maret 2018.

8. Escolar, A.G., Martinez, A.C., Pulido,J.M.G., Martinez, J.M.G., Stapic, Z., Merodio, J.A.M., 2015. A Sutdy to Improve the Quality of Street Ligting in Spain, Energy, ISSN 1996-1073, Vol.8, p976-994.

9. Biswas, B., Mukherjee, S., Ghosh, A., 2013, Conservation of Energi : a Case Study on Energi Conservation in Campus Lighting in an Institution, International Journal of Modern Engineering Research (IJMR), ISSN : 22496645, Vol.3, Issu 4, Jul-Aug.2013. 